not been from arm to arm, I have wasted so little time as almost to have conveyed warm matter in capillary tubes.

I have always borne in mind the importance of arm-toarm vaccination; and in the town of Winslow itself have carried it out, as far as possible, by arranging my cases in as much order of succession as I could command. In the villages, however, this method is most difficult to practise, and I have therefore had recourse to lymph stored in capillary tubes. I am most careful that the children from whom I obtain my supplies should be healthy, and I label my tubes with name and date of taking the matter.

With Weir's vaccinator I make three separate scratches on one arm, just long enough to admit of crossing them at right angles with the same instrument. As soon as the parts become slightly reddened, I blow the contents of two tubes upon the abraded surface, and gently rub in the lymph with the tip of the finger. Thanks to the kind teaching of my friend Mr. Robert Ceely, of Aylesbury, I have not for some years used points; and, since I have discarded them, I have been much more successful. I obtain a conglomerate vesicle of the size of a threepenny-piece, and a well-marked and permanent cicatrix.

2. The difficulties to be contended against, and how they have been overcome.-Arm-to-arm vaccination has been to me a very great difficulty, not only from the small number of cases (averaging 150 yearly), but more particularly from $\mathrm{my}$ widespread district. In my own immediate neighbourhood I can carry it out to a certain extent; but in my remoter villages $I$ cannot do so. It is impossible to take children from parish to parish; no funds are forthcoming for that purpose, even if the parents would consent to such a course. Supposing, again, I took a child with me at the appointed time, the mothers of the children to be vaccinated might, and probably would, object in some way to the child itself; and thus all my trouble would have been in vain. On this point the Inspector of Vaccination has suggested " that the periodical visit should take place every six months. One child might then be vaccinated, and the parents of the others told to come again the following week." The theory of this may be very plausible; but the objections would be that the parents might not like the child first vaccinated, or that, having come perhaps on a cold, wet day with a young child from a distance, they did not intend coming again. Who can compel them to do so? Another objection would be in the fact that all notices are issued worded in this way:- - Dr. Newham will attend at such a place, and on such a day, to vaccinate all children brought for that purpose." Again : the Vaccination Act says that all persons are liable to legal proceedings for non-compliance with its provisions if their children are not vaccinated before they are three months old. It passes my comprehension to understand how the Act is to be enforced if the visits are to be made at intervals of six months. I have, therefore, to the best of my ability, obviated this difficulty by taking recent matter and operating upon all children present at the station at the same time.

Scarcely second to the difficulty of arm-to-arm vaccination is the objection entertained by some parents to the performance of this operation. For some years no case of small-pox has occurred in my district, and I am happy to say that this objection has been gradually dying out. Among my private patients I have no difficulty. In spite of anti-vaccination platform orators, the good, common sense of Englishmen will assert its sway. Not only is this the case among the better educated classes of the community, but I find day by day the same feeling becoming more prevalent among the poor. When this objection is made, it is generally upon the ground of eruptions or some other diseases having followed the introduction of the vaccine virus. To meet this diffculty I do not argue about any results of vaccination;-

$$
\begin{aligned}
& \text { "A man convinced against his will } \\
& \text { Is of the same opinon still"; - }
\end{aligned}
$$

"s of the same opinion strll" ;-

but I inform all parents of the name of the child from whom tho matter is taken; that it is lymph I would put into my own children; and last]y, when a little gentle pressure is required, that the tet of Parliament is for rich and poor alite, and all must obey it. I have only had recourse to legal proceedings in three cases, in each of which the child was afterwards raccinated, and the parents at my request) muicted only in the costs. 'The magistrates have uniformily supported me, and for that support I am giateful.
One other difficulty is, I imagine, always in the way of public vaccinators; it is the proper carrying out of the Act with due regard to medical etiquette as to cases attended by other private practitioners. This difficulty is to be met, not by the public vaceinator constituting himself the public prosecutor, but by letting it be known that he is ready to vaccinate all children free of charge at certain hours. If the patients of other medical men voluntarily submit their children to him for vaccination, I think he is committing no breach of etiquette by acceding to the demand. On the other hand, if they do not do so, I consider it is no part of my duty to compel them ; but I make it a rule occasionally to inform $m y$ medical brethren who have attended private patients in my district what children under their care are not vaccinated.

3. The results.-At this time of writing (irrespective of cases to be vaccinated by other medical men) I have thir teen children only unvaccinated under the age of three months, and the whole of them are not due until periods varying from Angust 25th to October 29th. Two villages in my district are so distant as to be attended by another medical officer. I believe them to be well cared for in this way. In the remaining parishes which constitute my own personal charge, every child born during the last four years, if living, and not having left its parish, has been thoroughly vaccinated; in the vast majority of cases before it has been three months old, and in all cases as near that age as has been consistent with my periodical visits. For two years I have not had an unsuccessful case, and I attribute this to the use of Weir's vaccinator and of liquid lymph. To avoid even the chance of failure, I use recently charged tubes as a rule; but I have occasionally used matter which has been preserved some time, and I can safely assert that so far from its having deteriorated, I have produced vesicles from lymph four years old not to be distinguished from those in arm-to-arm vaccination.

One word more to conclude a subject in which I take great interest; so great, indeed, as to imperil its existence in the columns of THE LANCET on account of its inordinate length. I plead guilty to not having satisfied the inspector upon two points-viz., insufficient arm-to-arm cases, and allowing my assistant to operate (although this has not been the case except I was present, or saw the child at the proper time, and certified). Unwittingly I have not fulfilled the requirements of the Act, and I have been punished by the refusal of extra remuneration. After reading this paper, the profession must judge and pardon my sins of omission. For my own part I can sincerely affirm that I have honestly and conscientiously tried to do my duty.

Winslow, August 16th, 1870 .

NOTES OF A CASE OF

\section{STRANGULATED INGUINAL HERNIA IN}

\section{A BOY OF NINE MONTHS.}

\section{BY ARTHUR ANDREWS, M.R.C.S., L.S.A.}

EDwin $\nabla-$, aged nine months, was first seen on the 25th of May. He was then suffering from a right inguinal hernia as large as a small hen's egg. The scrotum covering it was tense, shining, and red. The hernia, which was congenital, had been down since the morning of the $23 \mathrm{rd}$. There was constant vomiting, and the bowels had only been slightly open on the afternoon of the 24th. The child was pinched and very pale; pulse quick and small; very restless; no marked tenderness of the abdomen. Taxis, with warm bath and afterwards chloroform, failed to reduce it, and I performed the ordinary operntion. The sac contained a laroe quantity of intestine and about half an ounce of clear yellowish fiuid. The wound was closed by two silver sutures, and a pad of lint applied. He recovered well from the chloroform, and in the evening took some milk. At 8 P.M. he was much quieter, and had only been sick once. During the night he cried very much and was very sick; and at 11 A x. on the 26th it was found that the hernia again protruded. Chloroform was again necessary for reduction, and then the hernia was retained by a firm pad of lint held in position by a long piece of strapping applied. 
down the back across the right side of the perineum orer the pad, and then up the front of the body and over the left shoulder. Another piecs was put on in spica form to prevent the pad slipping aside. He was ordered balf-drop doses of tincture of opium every three hours if in pain. His pulse was certainly slower and of better volume.

MIay 27 th.-Better; takes the breast well; has only been sick once, and is much quieter; hernia quite retained; the bowels well open; no tenderness of abdomen.

2Sth. - Pad removed; wound suppurating throughout; sutures removed, and the pad replaced as before; scrotum swollen, red, and œdematous.

29th.-Much better; free discharge from wound; scrotum not so inflamed; pulse slower; looks better; takes food well.

31st.-An abscess which formed in right flank (apparently from the wound being closed by the pad) was opened; has cut two teeth since the operation; better in health; bowels regular.

June 2nd.-Abscess has discharged freely; wound almost healed; pad still required to retain hernia. Ordered five minims of syrup of iodide of iron three times a day.

6th. - Abscess closed; wound healed, except about a quarter of an inch, which is quite saperficial; no impulse is now felt when the child cries. Pad replaced.

10th. - The child pulled the pad off, and the hernia prolapsed, but was easily reduced and the pad reapplied.

All went on well, and on June 23rd a truss was appliedthat is, at an interval of a month from the operation.

I wish to draw attention to the difficulty of retaining the hernia, which could not be accomplished in the ordinary manner, but was effected by the use of strapping at first as described above, and afterwards by the use of the piece passing over the perineum to the shoulder alone.

Farnham, June 28th, 1870 .

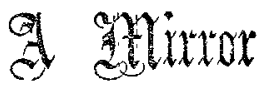

\section{OF THE PRACTICE OF}

\section{MEDICINE AND SURGERY IN THE}

\section{HOSPITALS OF LONDON.}

Nulla autem est alia pro certo noscendi via, nisi quamplurimas et morborum at dissectionum historias, tum aliorum, tum proprias collectas habere, et inter se comparare.-Morgagrr De Sed. et Caus. Norb., lib. iv. Procmium.

\section{LONDON HOS P T T L. RECENT OPERATIONS.}

ON Wednesday, July 3rd, Mr. Maunder performed lateral lithotomy on a boy aged seven, and removed a stone the size of a large hazel-nut. The nucleus was uric acid, and it had an outer coating of phosphates. The patient passed water by the natural passage in less than a week.

Mr. Tay amputated the arm of a man just below the tuberosities. The poor fellow had had his arm crushed a few days before by a machine at some gutta-percha works; his brachial artery was ruptured, the brachial plexus torn across in part, and the humerus fractured and somewhat comminuted. The injury was not compound; but there was some laceration of the skin of the upper arm. He is progressing favourably.

Mr. M'Carthy removed a large fatty tumour from the outer side of a woman's arm. In the skin covering it were some dilated veins, and to the touch it rather gave one the idea of being a fibro-cellular growth, or of having a hard, fibrous nucleus. On removal, however, it was found to be a good specimen of a fatty tumour, lobulated, and with its central portion more condensed tban usual.

The same surgeon performed IIr. Colles's operation for barelip on an infant who had also a cleft hard and soft palate.

Mr. Reeves tied the femoral artery of a man who was admitted a week before with a punctured wound into the knee-joint. Four dars after admission hæmorrhage came on, and as the tournirivet, cold, pressure, and position failed to arrest it, Mr. Reeves enlarged the wound, and emptied out all clots. As the bleeding appeared to be venous, he removed the tourniquet (which had caused considerable œdema of the thigh), and plugged the wound Fith lint steeped in iced water, at the same time ordering the leg to be raised. and ice apvlied. The bleeding did not return; but as in a couple of days free suppuration began to take place in the joint and tissues of the thigh, at Mr. Maunder's suggestion, Mr. Reeves tied the femoral. The next day the amount of pus secreted was diminished by half.

MIr. Maunder has also lately tied the brachial for severe inflammation of the hand.

On Wednesday, Tuly 10th, Mr. Tay removed a phosphatic stone from a boy by the lateral operation. He made a small internal incision, and in three days the boy passed urine by the natural passage. Mr. Reeves excised the right knee-joint of a boy aged twelve, who had received a kick on it two years ago. The joint had inflamed, and ever since, in spite of varied treatment, had been a source of great trouble to the lad. At the request of his parents, and with his own consent, the joint was excised. The synovial membrane was much thickened and degenerated, the cartilages ulcerating in one or two places, and there was a small cavity in the head of the tibia.

On Saturday, Jul 513 th, MIr. Reeves disarticulated at the hip-joint in a woman, the subject of a malignant tumour of the thigh. The growth extended high up, and surrounded the acetabulum, and could be felt above Poupart's ligament. The operation, which was in consequence a complicated one, was performed withont difficulty; the wound was mopped ont with strong solution of chloride of zinc, and the suspicious parts of it touched with the solid chloride. The woman rallied somewhat from the operation, but sank fifteen hours afterwards. We are informed that this was the third amputation at the hip at this hospital for malignant growth during the last eighteen months, the other two having lived some months, but ultimately succumbed to the disease.

Mr. Reeves has also recently excised the wrist-joint of a woman by a modified operation. He reflected a semilunar skin flap from the dorsum, separated and lifted up the extensor communis, divided the extensor carpi ulnaris and the ligaments, and removed all the diseased carpal bones, the ends of the metacarpal, and an oblique slice of the ulna, leaving its styloid process. The case does not appear to be a very promising one, as the skin is not sound, and the woman is middle-aged.

\section{WESTMINSTER HOSPITAL.}

CARBUNCULAR ABSCESSES OF THE BACK; TREATMENT BY YEAST PUULTICES AND INCISION.

(Under the care of Mr. Holthouse.)

THE case which we note has been lately in the hospital, and at our last report was doing well. It presents some peculiarities which seem to make it worth recording. Mr. Richard Davy, surgical registrar to the hospital, has obliged us with notes of it.

A. Won Aug. 9th with two carbuncles on his back. That on the left side (which has been coming on gradually for two months) is situated between the scapula and the dorsal spines, measures five inches by three, and projects backwards of the size of a cocoa-nut. The skin orer it is blanched and wash-leather-like in appearance. Fluctuation is distinctly felt keneath the skin. 'The carbuncle on the right side is as big as a bantam's eor ; is placed on the corresponding surface, but more distant from the spinal column; and presents, though in a less marked degree, the same characteristics as the other. Some three or four furuncles surround each. The patient's urine contains no sugar. He was prostrate and sweating much by night and dar, but not complaining of much distress. He was ordered reast poultices, with decoction of bark and nitric acid. On the following day Mr. Holthouse made a free longitudinal incision into the left swelling and let out eight ounces of pus. A smaller quantity was also removed by an opening made in to the right. 